\title{
Bourdieu and Critical Autoethnography: Implications for Research, Writing, and Teaching
}

\author{
Deborah Reed-Danahay \\ University at Buffalo, SUNY \\ U. S. A.
}

\begin{abstract}
This article argues that by combining critical ethnographic and autoethnographic perspectives we can move beyond the insider/outsider dualism, better understand the ways in which stories of personal experience are "strategic," and interrogate the broader contexts and processes of social inequality that shape life trajectories. The potential contributions to critical autoethnography of the reflexive approach of "self-analysis" advocated by Pierre Bourdieu are discussed. The author draws upon her uses of critical autoethnography in research (in France and the United States) and in teaching about immigration.
\end{abstract}

KEYWORDS: ethnography; Pierre Bourdieu; insider/outsider; immigration; critical autoethnography

\author{
Autoethnography and Ethnography in Dialogue \\ Bourdieu, Personal Narrative, and Self-Analysis \\ Teaching with Critical Autoethnography \\ Conclusion \\ References \\ Author Contact
}

Critical autoethnography, when viewed as a genre of research and writing that both takes into account personal experience and becomes an "anthropology as cultural critique" (Marcus \& Fischer, 1986), can contribute to our knowledge of power and social inequality. One of the first essays to draw attention to the insights critical theory brings to autoethnography in the field of education (Burdell \& Swadener, 1999) was a review article that discussed the use of personal narrative in several books published in the 1990s. Although the authors did not explicitly use the term "critical autoethnography," they argued that it was crucial to acknowledge the contested nature of concepts such as the self or identity and that any personal narrative should be subject to the question, "Whose interests are being served?" (p. 25). The main point of that article, which continues to resonate for me, was that personal narratives (including autoethnographies) should not be taken at face value but, instead, interrogated for the social positionings they entail. The term "critical autoethnography" has been increasingly visible in the literature. In the introduction to their recent edited volume on this genre, Boylorn and Orbe (2014) describe critical autoethnography as incorporating three aspects of critical theory: "to understand the lived experiences of real people in 
context, to examine social conditions and uncover oppressive power arrangements, and to fuse theory and action to challenge processes of domination" (p. 20).

Pierre Bourdieu did not use the term autoethnography and no doubt would have mistakenly associated all of its deployments with a certain form of narcissism that he abhorred. However, I see many links between what he called "reflexive sociology" and critical autoethnography. My earliest work on autoethnography (Reed-Danahay, 1997a) did not delve very deeply into this connection, but my later engagements with the work of Bourdieu (e.g., Reed-Danahay, 2005b) have led me into further explorations of the relationship between what he called "self-analysis" and critical autoethnography. This article will draw upon those affinities and is composed of three parts: first, I summarize the origins of my interest in and uses of autoethnography as a form of critical inquiry; then, I turn to some discussion of the implications of Bourdieu's approach for critical autoethnography; and finally, I share some of the ways in which I incorporate autoethnography in my teaching about social injustice and the ways in which social actors respond to it.

\section{Autoethnography and Ethnography in Dialogue}

I view autoethnography as a genre of writing that places the self of the researcher and/or narrator within a social context (Reed-Danahay, 1997a, 2017). It provokes questions about the nature of ethnographic knowledge by troubling the persistent dichotomies of insider versus outsider, distance versus familiarity, objective observer versus participant, and individual versus culture. As I have argued (ReedDanahay, 2009), it is more productive to see autoethnography as lying at the intersection of insider and outsider perspectives, rather than setting up a dualism that privileges the insider account. Autoethnography reflects a view of ethnography as both a reflexive and a collaborative enterprise, in which the life experiences of the anthropologist and their relationships with others "in the field" should be interrogated and explored. My own interlocutors include the research participants I encounter during ethnographic fieldwork, who may narrate stories to me that I view as autoethnographic, and published writers of texts that I consider autoethnographic. Autoethnography is an umbrella term that can refer to autobiographical narratives about the doing of ethnography or being an ethnographer, to the work of an anthropologist doing ethnography in their own society (the so-called "native anthropologist"), and to genres of fiction and memoir that incorporate an ethnographic (or "counter-ethnographic" - see Watson, 2013) sensibility about the author's own cultural milieu.

Although the introduction to my edited book Auto/Ethnography: Rewriting the Self and Social (1997a) is widely cited in the literature on autoethnography, another chapter that I wrote for that volume (Reed-Danahay, 1997b) is less well known. It concerns what I consider to be the autoethnographic productions of people who were the children of French peasant families but eventually became educated, moved away, and later wrote memoirs that described what it meant to "leave home" in both a geographical and an emotional sense. Contemporary discussions of cultural difference in France focus 
primarily on immigrants and refugees. However, France was a nation formed through efforts to assimilate the diverse regional populations (many of whom also spoke regional languages or dialects) within its territory. The tensions between rural and working-class families and teachers in France have long been shaped around some of the same issues that are now being raised regarding immigrant families (see ReedDanahay \& Anderson-Levitt, 1991). I became interested in stories written by people who grew up in a rural milieu as an anthropologist who had previously conducted fieldwork on education in rural France (Reed-Danahay, 1996). I was intrigued by the dialogue between my own ethnographic research (as an American woman and therefore an outsider who tried to understand what Malinowski called "the native point of view") and the perspectives articulated by writers who were native to rural France but had also come to adopt a similar ethnographic stance of distance due to their having left that milieu. These authors began their lives as insiders, but had become familiar enough with the world beyond to develop the desire not only to write about their own life experiences for a broader audience but also to convey ethnographic details about the peasant milieu of their childhood. These writers, Pierre Jakèz-Hélias (1978) and Emilie Carles (1991), were autoethnographers. Their memoirs can be viewed as a form of indigenous ethnography that builds upon personal experience. Rather than being overly concerned with the "authenticity" of their narratives as ethnographic reportage, I was more interested in the social and cultural conventions and values regarding education in France that they conveyed. I was also interested in the variety of responses to the assimilationist ethos of the French nation as implemented through education that their texts revealed. I subsequently published three more essays (ReedDanahay, 2002, 2005a, 2006) on the published autobiographies of people with rural French backgrounds.

When I later turned to research among former Vietnamese refugees and their children in north-central Texas (Reed-Danahay, 2012; Brettell \& Reed-Danahay, 2012), I was also drawn to the autoethnographic aspects of memoirs written by the children of Vietnamese refugees (Reed-Danahay, 2015). I was interested in how they narrated their experiences and what they could teach me and my students about the social contexts and emotional responses of a child in such circumstances, as well as the ways in which "diaspora" is framed through memoir. Although my research participants were valuable sources of information on personal experience, those who write and publish memoirs on their experiences may rely more on certain tropes of storytelling that can reveal aspects of the social positioning of the author. This takes me back to the question I raised earlier, posed by Burdell and Swadener (1999), of "whose interests are being served" in the writing of immigrant or ethnic memoir (p. 25).

Therefore, my interest in autoethnography, as an ethnographer who pays attention to the multiple narratives told on behalf of the populations I study, draws me not only to research participants who speak to me and tell me stories "in the field," but also to those who write and publish their accounts and make them available in the wider public sphere. I am interested in the dialogue between my own ethnographic work and the writings of those other authors. Their autoethnographies supplement and enrich my own ethnographic perspectives. However, as a scholar who advocates a critical autoethnographic perspective, I do not blindly accept the authenticity of the 
autoethnographies in comparison with ethnography composed by someone who cannot claim to be a "native." A critical ethnographic perspective seeks to understand the social conditions that produce both autoethnography and ethnography. Such a perspective also informs Julia Watson's recent analysis of Esmeralda Santiago's memoir When I Was Puerto Rican as a "strategic autoethnography" that works to challenge patriarchy while also negotiating the ethnic memoirist's role as "cultural insider and literate, reflexive outsider" (Watson, 2013, p. 146). I have found the work of Pierre Bourdieu instructive in thinking about these issues of both authenticity and the insider/outsider dualism because it challenges assumptions about the impulses of autobiography.

\section{Bourdieu, Personal Narrative, and Self-Analysis}

Although they did not use the term "autoethnography," predating its widespread use, two volumes published in 1992 captured a trend toward more reflexive and critical approaches to ethnographic writing. The collection Anthropology and Autobiography (Okely \& Callaway, 1992) appeared that year, as did An Invitation to Reflexive Sociology (Bourdieu \& Wacquant, 1992). The first book, edited by Judith Okely and Helen Callaway, includes personal narratives by several anthropologists who share their experiences in the field in order to open up space for discussion of the role of the anthropologist as a person in the construction of knowledge through ethnographic research. The second book is an elucidation of Bourdieu's methodological approach of reflexive sociology. Although both books were aimed at critically examining the conditions for the production of academic knowledge through ethnographic research, Pierre Bourdieu's approach to reflexivity was somewhat different from that of Okely and Callaway, who hoped to bring together autobiography and anthropology. For Bourdieu, reflexivity was an intellectual stance that he called "anti-autobiography" (Bourdieu \& Wacquant, 1992, p. 213). He used the notion of reflexivity to refer to social science writing that does not privilege the individualism of the author (which he felt was the misguided standard approach of autobiography) but, rather, reflects an awareness of the researcher's positioning in various social fields and social spaces, as well as a broader critique of the ways in which social science constructs its objects. The point of being self-reflexive for Bourdieu was neither to expose the researcher's feelings about fieldwork or informants, nor to validate the researcher's credentials as fieldworker in the way that what Van Maanen (1988) referred to as "tales of the field" may work to do. According to Bourdieu, reflexivity is a methodological approach in which one critically examines one's own position within the field of academic production-not in order to be more objective and less subjective, but rather to understand the false distinction between these two categories. Bourdieu (2003b) advocated a methodology of "participant objectivation" in ethnographic research and argued that there is no absolute objectivity or subjectivity possible.

Bourdieu used methods that I label autoethnographic both in writing related to his own life trajectory and in writing that drew upon the personal narratives that he collected during fieldwork. For example, in the volume Weight of the World, Bourdieu used the 
concept of testimony (temoignage) to refer to interviews collected among working class and immigrant French people and the teachers and social workers who interacted with them (for a more detailed discussion of this, see Reed-Danahay, 2005, pp. 145-48). The juxtaposition of various autoethnographic narratives in the book permits a wider picture of the social sphere in which less privileged children struggle. These personal narratives also show differences in "habitus" for the various characters who shared their life experiences with Bourdieu. For example, he spoke to the child of Algerian immigrants who was 20 years old at the time of the interview. This youth had pursued more education than his peers in a housing project north of Paris, and Bourdieu was interested in this young man's own commentary on that while also analyzing, as a sociologist, some of the conditions that made it possible. The youth was insecure about his chances for school success, constantly worrying about failure. He had the sense that his own experience was disconnected from the neighborhood in which he grew up. This boy's father earned a decent wage and his parents encouraged him to succeed in school (Bourdieu et al., 1999, pp. 60-61). Bourdieu juxtaposed this story with that of two school dropouts, interviewed together, whose experiences were quite different. One was the child of Moroccan immigrants and the other from a poor French family. Both of these youths had rejected the school system and felt that the teachers did not care about them. As one remarked, "In our [housing] project no one goes to school" (p. 66). The first youth (with Algerian parents) pursued schooling, albeit with many insecurities about his ability to succeed, while the second two reject a system that they feel does not care about them anyway. For Bourdieu, the attitudes of these youths regarding their chances for school success, and their desires regarding education, are indicative of forms of symbolic domination. The fatalism of the second two youths is related to their social origins, both living in poverty and the boy with Moroccan parents lacking sufficient French language skills. Listening to the testimonies of these young men, their autoethnographic expressions of how their lives have unfolded so far and of their desire or rejection for schooling, permits Bourdieu to make an argument that those who are dominated accept the "destiny" associated with their position of domination.

Bourdieu also collected personal narratives among Algerian workers during the immediate postcolonial period in Algeria. He labeled one of his interviewees, an Algerian cook, as a "spontaneous sociologist" (Bourdieu, 1963, p. 508 [my translation]) and later as a "spontaneous economist" (Bourdieu, 2003a, p. 85 [my translation]). These terms are closely related to the idea of autoethnography as indigenous ethnography. This cook, because he had travelled widely both geographically and among different social circles, had developed a sensibility that permitted him to have a perspective of both distance from and familiarity with his own social sphere and his own life trajectory. He could, therefore, articulate his understanding of the capitalist (European) and pre-capitalist (Algerian) worlds and his own economic marginality within the new postcolonial economy. Although Bourdieu argued that people are rarely aware of their own circumstances and cannot usually articulate them clearly, occasionally there are individuals like the cook whose life experiences permit the sort of "distancing" necessary for ethnographic or sociological analysis. Critical autoethnography likewise entails a blend of distance and familiarity, analysis and testimony, as used by Bourdieu in some of his own work. 
In addition to his attention to personal narratives recorded during fieldwork, much of Bourdieu's work is also autoethnographic if that means research as a "native" ethnographer in one's own milieu. He conducted research in his natal village in the rural southwestern part of France, relying upon his own mother as one of his research sources (Bourdieu, 2008b). Moreover, Bourdieu's books Homo Academicus (1988) and The State Nobility (1996) can be considered critical autoethnographies in that they are both ethnographic and sociological studies of higher education in France, a system that Bourdieu knew very well from his own position and participation within it.

By far Bourdieu's most direct deployment of critical autoethnography was, however, in his book Sketch for a Self-Analysis (2008a), published posthumously in France in 2004. An inscription on the first page of that book states, "This is not an autobiography." Such a statement must be understood in relationship to Bourdieu's rejection of the conventions of autobiography that he argued were an "illusion" (see Bourdieu 1986). Autobiographies were associated with narcissism and self-indulgence for Bourdieu. Furthermore, he criticized biography and autobiography for frequently ignoring the social space in which a life was lived. By this, Bourdieu meant the constraints and possibilities afforded to persons due to their social origins - primarily, their habitus as an embodied orientation to the world that informs tastes, aspirations, emotions, and positioning in relationship to others. The "space of possibilities" (2008a, p. 4) in which a person is situated in life and which forms the basis of the choices they make, must be taken into account. When Bourdieu set out to write about his own life trajectory, he did so as a "reflexive" sociologist. He applied the method of "selfanalysis," in order to chart his "path through social space" (2008a, p. 1). The focus of the book is on his intellectual trajectory and reveals little in terms of his personal or intimate life, although he makes reference to his family of origin and his childhood.

Why do I link this book to critical autoethnography? First, in order to understand processes of domination, injustice, and inequality, it is important not to invest in the "biographical illusion" (1986) criticized by Bourdieu when using autoethnographic methods in research, writing, and teaching. For Bourdieu, habitus is not something to be viewed as a unique possession of an individual. Rather, any person's habitus shares affinities with those who grew up in a similar social milieu, positioned in a similar way within social space and following similar life trajectories. Although there will be variations among individuals in terms of the choices they make in life, partly due to opportunities presented to them and partly due to their own inclinations, habitus is a concept meant to challenge the view of the individual as having "free choice" that does not take into consideration the economic, cultural, and symbolic capital available to them from which they carve out their lives. Critical autoethnography takes into account the positions and positionings of its narrator within systems of inequality.

In teaching with autoethnography, I hope to challenge my students to think about their own lives and those of people with different experiences from their own by using a critical and reflexive approach. Although it is not possible in most of my classes to delve into Bourdieu's theories in depth, his perspectives inform my approach to teaching about inequality and diversity. 


\section{Teaching with Critical Autoethnography}

My teaching at the university level incorporates the use of autoethnography in two main ways: I have students write autoethnographies, and I have them read autoethnographies. I do this so that they may become better at reflexive analysis and also better at critical analysis. I want them to link their own experiences with those of the people whose stories they read, but also to be critical thinkers who ask questions about the social contexts and power relations that inform life trajectories. I also want them to understand their own positionings within the realms we investigate in class. One of the assignments early in the semester of my undergraduate courses on migration and on anthropology and education is for each student to compose a written autoethnography about their own experiences (with migration in the first case and with education in the second). I first explain the differences between autobiography and autoethnography, often employing the metaphor Pierre Bourdieu used in discussing the problems with the notion of the individual in most autobiography. He wrote (1986) that we cannot understand the trajectory of a subway train if we do not also take into account the infrastructure that surrounds it in the underground tunnels through which it travels or the various station stops it makes. We are not, therefore, as we frequently perceive ourselves to be, autonomous individuals whose lives are freely chosen. I try in this way to convey the idea that autoethnography places the self within a social context, which is for me one of the hallmarks of autoethnography. There are three main lessons that I hope to teach through this exercise. First, I want students to become more reflexive about their own experiences and the ways in which their lives have been shaped by social and cultural forces (rather than being due entirely to individual preference and choice). Second, I want to encourage students to be more empathetic toward the migration and/or educational experiences of people about whom they will read during the semester who might at first glance be seen as very different from themselves. Third, I want to teach about social inequality and issues of social justice through this exercise, by showing students that where they come from (e.g., socioeconomic background and family, gender, ethnicity, and geographical location) does not entirely determine their life trajectory but can certainly influence it in profound ways by providing opportunities and obstacles. Although it is quite often uncomfortable for White, middle class students in my classes to discuss their positionings in social space, this comes more easily to students of color and/or of immigrant background because they are frequently more aware of the structures of inequality due to experiences of racism or anti-immigrant sentiments. I do not have students read each other's autoethnographies, but the discussions that we have after they have written them provoke insightful understandings of how our own social origins and experiences must be seen as jointly influencing (but not necessarily determining) our worldviews and life trajectories.

I also have my students read autoethnographies in my classes. In my teaching on migration at both the undergraduate and graduate levels, I have found three books to be particularly useful in helping students learn about the lived experience of migrants 
and the processes of domination frequently encountered by them. Because they convey the personal narratives of migrants, these texts provide useful supplements to ethnographic studies. One is explicitly labeled as an "autoethnography," one is a work of fiction, and one is an ethnic memoir. The first (Khosravi, 2010) is an autoethnographic account written by a man who began his migration journey as an "undocumented" migrant from Iran and eventually became an anthropology professor at the University of Stockholm in Sweden. His personal account of his departure as a youth to avoid military conscription and his multiple attempts to reach Europe before eventually doing so, provide students with a first-person account of life "on the road." Khosravi writes about dealing with border guards and human smugglers, and about obtaining travel documents. This book also teaches about borders, struggles, survival in difficult circumstances, and concepts of both legal and cultural citizenship. It is a critical autoethnography because it clearly positions the author in the framework of mobility and migration and provides a balance between insider and outsider perspectives. It questions the regimes of control at borders and concepts of "deservingness" regarding the treatment of migrants. The book is subtitled "an auto-ethnography of borders" to signal that it is not an autobiography but a tale of borders through the story of this man's experiences.

The second autoethnographic text that I use is the novel Kiffe Kiffe Tomorrow (Guène, 2006), written from the perspective of a teenage girl of Moroccan heritage living in the suburbs north of Paris. This book is autoethnographic because it combines an autobiographical perspective with an ethnographic one, providing a "slice of life" portrait of what it is to live as the child of immigrants in contemporary France. The narrator, Doria, tells us about her interactions with teachers, social workers, and a therapist provided by the social welfare system of France and in response to her family's situation. She lives with her mother only, who is working as a hotel maid at the start of the narrative, because her father left them to return to Morocco. With a somewhat humorous and skeptical eye toward the social space within which she lives, Doria explains why it is hard for her to feel fully French in comparison with those she labels "full-blooded native French" living nearby (p. 81). She considers France to be "her country" and helps her mother to learn the French language, but is aware of her mother's ties to the homeland of Morocco. This book helps students understand the sensibilities and emotional responses of the children of immigrants. The injustices of her situation are not lost on Doria, as she also observes the responses of those around her. Among my students who are, themselves, of recent immigrant background, as well as among those whose families have lived much longer in the United States, the book provokes interesting discussions about belonging and the incorporation of migrants in contemporary societies.

The third book, which is a non-fiction ethnic memoir written by Bich Nguyen, the daughter of a Vietnamese refugee who arrived in the United States as an infant, incorporates the same blend of autobiography and ethnography as the other two books I have mentioned. Like them, it is a good book "to teach with" about immigrant experiences-especially when viewed through the lens of critical autoethnography. Stealing Buddha's Dinner (Nguyen, 2007) is set not in the type of immigrant neighborhood where Doria lives in France, but in a primarily "White" Midwestern city in 
which the author's family stands out quite vividly as "different." Bich describes her childhood very much through a child's eyes, trying to understand the adults around her and her conflicting desires to be "American" like her friends at school and to be accepted by her Vietnamese relatives and family friends. Her life is haunted by the war and its aftermath, and especially the loss of her mother, left behind when her father and grandmother fled Vietnam with her and her sister as Saigon fell in 1975. As in the novel Kiffe Kiffe Tomorrow, the ways in which social milieu and relationships of power affect the protagonists' lives are not always explicitly spelled out by the author. However, through class discussion and supplementary background material, a critical autoethnographic perspective can be conveyed. Students thereby come to understand that although the lives portrayed are in many ways unique, the wider social and political processes that surround migration and its effects on subsequent generations are vividly illustrated through these stories.

\section{Conclusion}

Although educational institutions are themselves sites of power and conflict in stratified societies, in which competing claims for dominance are enacted, they are also potential locations for intellectual growth and discovery, as many of us employed as professors hope to be the case in our own teaching activities. The term "critical autoethnography" may help distinguish between autoethnography that is focused primarily on the self of the researcher or writer and autoethnography that captures more of the reflexive approach of "self-analysis" endorsed by Pierre Bourdieu (2008a). With a critical and reflexive approach, we examine our own institutional and professional contexts with an eye not only toward a better understanding of ourselves as ethnographers, but also toward a more vigorous reflection on the institutional practices and fields in which we operate. By using both critical ethnographic and autoethnographic perspectives in our scholarship and teaching, we can potentially move beyond an insider/outsider dualism, better understand the ways in which stories of personal experience are "strategic," and interrogate the broader contexts of social inequality that shape life trajectories and the stories told about them.

\section{References}

Burdell, P., \& Swadener, B. B. (1999). Critical personal narrative and autoethnography in education: Reflections on a genre. Educational Researcher, 28, 21-26.

Boylorn, R. M., \& Orbe, M. P. (Eds). (2014). Critical autoethnography: Intersecting cultural identities in everyday life. Walnut Creek, CA: Left Coast Press.

Bourdieu, P. (1986) L'illusion biographique [The biographical illusion]. Actes de la recherché en sciences sociales, 62/63, 69-73. 
Bourdieu, P. (1988 [1984]). Homo academicus. (P. Collier, Trans.). Stanford, CA: Stanford University Press.

Bourdieu, P. (1996 [1989]). The state nobility: Elite schools in the field of power. (L. C. Clough, Trans.). Stanford, CA: Stanford University Press.

Bourdieu, P. (2003a). La fabrique de l'habitus économique. Actes de la Recherches en Sciences Sociales, 150, 79-90.

Bourdieu, P. (2003b). Participant-objectivation. Journal of the Royal Anthropological Institute, 9, 281-294.

Bourdieu, P. (2008a [2004]). Sketch for a self-analysis. (R. Nice, Trans.). Chicago, IL: University of Chicago Press.

Bourdieu, P. (2008b [2002]). The bachelors' ball: The crisis of peasant society in Béarn. (R. Nice, Trans.). Chicago, IL: University of Chicago Press.

Bourdieu, P., Accardo, A., Balazs, G., \& Beaud, S., et al. (1999 [1993]). The weight of the world: Social suffering in contemporary society. (P. P. Ferguson, S. Emanuel, J. Johnson, \& S. T. Waryn, Trans.). Stanford, CA: Stanford University Press.

Bourdieu, P., Darbel, A., Rivet, J-P, \& Seibel, C. (1963). Travail et travailleurs en Algérie. Paris and the Hague: Mouton.Brettell, C. B., \& Reed-Danahay, D. (2012). Civic engagements: The citizenship practices of Asian Indian and Vietnamese immigrants. Stanford, CA: Stanford University Press.

Bourdieu, P., \& Wacquant, L. (1992). An invitation to reflexive sociology. Chicago, IL: University of Chicago Press.

Carles, É. (1991). A life of her own: A countrywoman in twentieth-century France. New Brunswick, NJ: Rutgers University Press.

Guène, F. (2006 [2004]). Kiffe kiffe tomorrow. (S. Adams, Trans.). Orlando, FL: Harcourt.

Jakèz-Hélias, P. (1978). The horse of pride: Life in a Breton village. New Haven, CN: Yale University Press.

Khosravi, S. (2011). "Illegal" traveller: An auto-ethnography of borders. New York, NY: Palgrave Macmillan.

Marcus, G. E., \& Fischer, M. J. M. (1986). Anthropology as cultural critique: An experimental moment in the human sciences. Chicago, IL: University of Chicago Press.

Nguyen, B. (2007). Stealing Buddha's dinner: A memoir. New York, NY: Penguin.

Okely, J., \& Callaway, H. (Eds.). (1992). Anthropology and autobiography. London, U.K.: Routledge.

Reed-Danahay, D. (Ed.). (1997a). Auto/ethnography: Rewriting the self and the social. New York, NY: Berg.

Reed-Danahay, D. (1996). Education and identity in rural France: The politics of schooling. Cambridge, U.K.: Cambridge University Press. 
Reed-Danahay, D. (1997b). Leaving home: Schooling stories and the ethnography of autoethnography in rural France. In D. Reed-Danahay (Ed.). Auto/ethnography: Rewriting the self and the social (pp. 123-144). New York, NY: Berg.

Reed-Danahay, D. (2002). Sites of memory: Autoethnographies from rural France. Biography: An Interdisciplinary Quarterly. Special Issue on Biography and Geography, 25, 95-109.

Reed-Danahay, D. (2005a). Desire, migration, and attachment to place: Life stories of rural French women. In B. Straight (Ed.). Women on the verge of home: Narratives of home and transgressive travel (pp. 129-148). Albany, NY: SUNY Press.

Reed-Danahay, D. (2005b). Locating Bourdieu. Bloomington, IN: Indiana University Press.

Reed-Danahay, D. (2006). Becoming educated, becoming an individual? Tropes of distinction and 'modesty' in French narratives of rurality. In V. Amit \& N. Dyck (Eds.). Claiming Individuality: The cultural politics of distinction (pp. 13152). London, UK: Pluto Press.

Reed-Danahay, D. (2009). Anthropologists, education, and autoethnography. Reviews in Anthropology, 38, 28-47.

Reed-Danahay, D. (2012). The Vietnamese American Buddhist youth association: A community of practice for learning civic skills. TSANTSA [Journal of the Swiss Ethnological Society], 7, 76-85.

Reed-Danahay, D. (2015). 'Like a foreigner in my own homeland': Writing the dilemmas of return in the Vietnamese American diaspora. Identities: Global Studies in Culture and Power. 22, 603-618.

Reed-Danahay, D. (2017). Autoethnography. In J. Jackson (Ed.). Oxford bibliographies in anthropology. New York, NY: Oxford University Press.

Reed-Danahay, D., \& Anderson-Levitt, K. M. (1991). Backward countryside, troubled city: French teachers' images of rural and working-class families. American Ethnologist, 18(3), 546-564.

Van Maanen, J. (1988). Tales of the field. Chicago, IL: University of Chicago Press.

Watson, J. (2013). Strategic autoethnography and American ethnicity debates: The metrics of authenticity in "When I Was Puerto Rican." Life Writing, 10,129-150.

\section{Author Contact}

Deborah Reed-Danahay: der5@buffalo.edu

Department of Anthropology, 380 MFAC, University at Buffalo, Buffalo, NY 14260-1660, USA 